\title{
Capturing the Implications of Services Trade Liberalization*
}

\author{
Sherman Robinson \\ International Food Policy Research Institute \\ Zhi Wang \\ United States Department of Agriculture, \\ Economic Research Services
}

Will Martin

The World Bank

\begin{abstract}
This paper evaluates the impact of service sector trade liberalization on the world economy by a tenregion, eleven-sector CGE model with import embodied technology transfer from developed countries to developing countries. Simulation results show that service sector trade liberalization not only directly affects world service production and trade, but also have significant implications for other sectors in the economy. The major channel of the impact is through inter-industry input-output relations and TFP growth induced from service imported by developing countries from developed countries, which may embodied with new information and advanced technology.
\end{abstract}

Keywords: Service trade liberalization, Inter-industry IO links, Import embodied technology transfer, and CGE model

JEL classification: F1, C68, O3

Forthcoming in Economic System Research Vol. 14(1), 2002

* Corresponding author: Zhi Wang, United State Department of Agriculture, Economic Research Services, Room 5141, 1800 M Street, NW, Washington, DC 20036-5831. Phone:(202)694-5242, Fax: (202)694-5793, E-mail: zwang@ers.usda.gov. The research for the paper was financially supported by the World Bank. The views in the paper are those of the authors, and may not be shared by any of the institutions that they are or have been associated with. 


\section{Capturing the Implications of Services Trade Liberalization}

\section{Introduction}

Trade in services became a major issue in the Uruguay Round of GATT negotiations, and is a continuing source of trade disputes since the round was completed. It will undoubtedly be a major issue in the next round of negotiations under World Trade Organization (WTO). "Services" cover a lot of different sectors, with very different trade issues. Large sectors such as banking, insurance, and financial services have become increasingly important as world trade has expanded, and opening external markets has become an issue for "producers" of these services in developed countries. Services in wholesale and retail trade and transportation are also very large sectors in most countries, with international trade largely linked to trade in commodities. Reduction in international "transactions costs" -- which include marketing, communications, trade, and transportation has been one of the engines driving the rapid expansion of world trade in the post-war period.

There are many conceptual and empirical problems in measuring output, prices, and trade volumes in the services sectors. Luanga and Yu (1999) describe the many difficulties of assembling a consistent data base of trade in services across the countries in the Global Trade Analysis Project (GTAP) data base. Looking at issues of "transactions costs" is even more difficult, since many of those costs would not appear as part of services (and services trade), but would instead be included as costs of production within firms producing commodities.

This paper is an exercise in empirical exploration. We start with the GTAP data base (version 4), which includes some detail in services, and build a multi-country, multi-sector, computable general equilibrium (CGE) trade model that focuses on the services sectors. We then use this model to explore the impact of changes in trade in services, including changes in technology and in protection. We also explore the potential empirical importance of technological externalities that are transmitted through trade in services, intermediate inputs, and capital goods.

Our goal is to find large numbers. What are the potential gains from liberalizing trade in services compared to trade in commodities? What would be the impact of further technological changes in 
transportation and reductions in international transaction costs? What are the potential gains from increased trade in an environment where there are externalities emanating from trade between developed and less developed countries? How important are forward and backward linkages between the services and non-services sectors in trading countries? While the current state of both trade theory and empirical work cannot yield definitive answers to questions such as these, we think we can make progress with an empirical model that is flexible enough to incorporate many of the important links and effects.

\section{Structure of the Model and Major Assumption}

The model used in this paper is a member of a family of multi-country models that have been used widely to analyze the impact of trade liberalization. Starting with Whalley (1985) and Deardorff and Stern (1990), who analyzed the impact of the Tokyo Round of GATT negotiations, a number of such models have been developed to explore the impact of the Uruguay Round and various regional trade agreements such as NAFTA, ASEAN, APEC, Mercosur. ${ }^{1}$ Our particular model was an extension of de Melo and Tarr's (1992) single country trade model to a multi-country framework by Wang (1994, 1997) and is described in detail in Noland, Liu, Robinson and Wang (1998). It is a close cousin of models developed by Lewis, Robinson, and Wang (1995) and Lewis and Robinson (1996).

The model focuses on real trade flows, world prices, and real exchange rates. It incorporates macroeconomic specifications from Devarajan, Lewis and Robinson (1990), as well as an international shipping sector similar to the GTAP model (Hertel, 1997). Given our focus on services and linkages through intermediate inputs, we have replaced the standard specification of a Leontief technology for intermediate inputs with nested constant elasticity of substitution CES production functions that allow substitution between value-added and aggregate intermediate inputs in the upper-level of the production tree. Links between trade performance and total factor productivity are also introduced into the model as an import-embodied technology transfer across regions via trade in

1 NAFTA stands for North America Free Trade Area; ASEAN stands for the Association of South East Asia Nations which includes ten member countries; APEC stands for Asia Pacific Economic Cooperation that has 21 members; Mercosur is a trade block in Latin American, including Argentina, Brazil, Paraguay, and Uruguay. 
intermediate inputs, which links a region's TFP growth with its imports of capital and technologyintensive products and professional services. The model is implemented using the General Algebraic Modeling System (GAMS), which is described in Brooke et al. (1988), and is specified and solved in levels.

The model includes ten regions and eleven production sectors in each region. The ten regions are: (1) the United Sates, (2) European Union (15 members), (3) Japan, (4) Other OECD countries, (5) Asian newly industrialized countries (Korea, Taiwan, Hong Kong and Singapore), (6) China, (7) ASEAN4 (Malaysia, Thailand, Philippines, Indonesia), (8) South Asia (Indian, Bangladesh, Nepal, Pakistan, and Sri Lanka), (9) Latin America, and (10) Rest of the world. Six of the eleven production sectors are services: (1) utilities, (2) construction, (3) trade and transport, (4) private service, (5) public service, and (6) housing. The other five sector are: (7) agriculture, (8) processed food, (9) natural resource based products, (10) non-durable consumer goods, and (11) intermediate and durable manufactures. Each region is assumed to have basically the same structure. Five primary factors of production are modeled: agriculture land, natural resources, capital, unskilled-labor, and skilledlabor. The division between skilled and unskilled labor is a distinction between professional workers and production workers. ${ }^{2}$ Agricultural land and natural resource are sector-specific, while capital and labor are assumed to be mobile across sectors, but immobile between regions.

\subsection{Production and Demand structures}

In each region, there is one representative competitive firm for each sector, which produces one product. Production technology is characterized by two-level nested CES functions. At the first level, firms are use two types of inputs: a composite primary factor and an aggregate intermediate input according to a CES cost function. At the second level, the split of intermediate demand is assumed to follow a Leontief specification, with no substitution among intermediate inputs. Technology in all sectors exhibits constant return to scale, implying constant long-run average and marginal costs. Sectoral output is assumed to be a composite commodity that can be transformed according to a

2 Professionals include International Labor Office (ILO) occupation groups 0-2, (professional, technical and related workers; and administrative and managerial workers). Production laborers are the aggregation of ILO occupation groups 3-5 (clerical and related workers; sales workers; and service workers) and 7-9, (production and related workers; transport equipment operators and laborers) plus agricultural labor. 
constant elasticity of transformation (CET) function between a good sold on the domestic market and a good sold on the world market (an export).

Agents in each region view products from different regions as imperfect substitutes (the Armington assumption). The private household in each region maximizes a Stone-Geary utility function over the eleven composite goods and savings, which leads to the Extended Liner Expenditure System (ELES) of household demand. Household savings are treated as a demand for future consumption goods with zero subsistence quantity (Howe, 1975). An economywide consumer price index is specified as the price of savings and represents the opportunity cost of giving up current consumption in exchange for future consumption (Wang and Kinsey, 1994). Government spending, and investment decisions in each region are based on Cobb-Douglas utility functions, which generate constant expenditure shares for each composite commodity. In each region, firm intermediate inputs, household consumption, government spending, and investment demand constitute total demand for the same Armington composite of domestic and imported goods from different sources. A two-level nested CES aggregation function is specified for each composite commodity in each region. Total demand is first divided between domestic and imported goods, then the expenditure on imports is further divided according to geographical origin under the assumption of cost minimization. Complete trade flow matrices for all regions are part of the model solution.

There is an international shipping industry in the model to transport products from one region to another. Each region is assumed to allocate a fraction of the output of its trade and transport sector to satisfy the demand for shipping that is generated by interregional trade. The global shipping industry is assumed to have a unitary elasticity of substitution among supplier sources. The margins associated with this activity are commodity/route specific. In equilibrium, the total value of international transportation services at the world price equals the sum of the export proportions of the service sector's output from each region.

\subsection{Equilibrium, Exchange Rate, and Macro Closure}

Within each region, the model solves for domestic commodity and factor prices that equate supply and demand in all goods and factor markets. The model also solves for world prices equating supply and demand for sectoral exports and imports across the world economy. In addition, for each region, 
the model specifies an equilibrium relationship between the balance of trade and the real exchange rate (which measures the average price of traded goods $\bullet$ exports and imports $\bullet$ relative to the average price of domestically produced goods sold on the domestic market). However, as with other CGE models, the model only determines relative prices. The United States is specified as the "reference" economy, with both its aggregate price level and exchange rate fixed exogenously. All relative world prices and trade balances are measured in terms of real U.S. dollars. Because traded and non-traded goods are assumed to be imperfect substitutes by sectors, changes in relative world market prices are only partially transmitted to domestic markets. The model thus incorporates a realistic degree of insulation of domestic commodity markets from world markets, but the links are still important and provide the major mechanism by which external shocks are transmitted across regions.

The exchange rate variable in the model is not a financial exchange rate. Under appropriate numeraire selection, however, it is equivalent to the "real exchange rate" defined as the ratio of a price index of all traded goods (imports and exports) to a price index of all nontraded goods (domestically produced goods sold at the domestic market). When the price index of home goods is selected as the numeraire, the percentage change in the real exchange rate is equal to the percentage change of the exchange rate variable in the model. In a multi-region model where all world market prices are endogenous, the equilibrium real exchange rate is affected by changes in the international terms of trade facing a region. Devarajan, Lewis, and Robinson (1993) and Wang (1994) discuss this issue. For each region, the model solves for the equilibrium real exchange rate given our assumption of a fixed trade balance and any changes in world prices.

For each region, the model includes three macro balances: savings-investment, balance of trade, and government expenditure-receipts (government deficit). The three balances are not independent and the determination of these macro balances is the subject of traditional macroeconomic models. In terms of our real trade model, which does not include financial markets or variables typical of macro models, the determination of these macro aggregates is specified by simple rules. The macro adjustment mechanism constitutes the macro "closure" of the model.

The specification of a macro closure is to select rules by which macro balances are brought back to 
equilibrium when exogenous shocks disrupt the benchmark equilibrium during an experiment. A macro scenario is imposed on the CGE model, which then traces out the sectoral implications of the assumed macro behavior (Devarajan, Lewis, and Robinson, 1990). The macro closure is not based on a specification of optimizing behavior by rational agents in the model, but reflects a simplified description of the results of a macro adjustment process which is not specified in detail.

Since the major purpose of this study is to evaluate the impact of service sector trade liberalization on the rest of the economy, we specify a simple macro closure designed to focus on welfare changes arising through changes in aggregate consumption. The balance of trade, government real expenditure, and aggregate real investment in each region are all fixed. If government revenue changes (e.g., because of a reduction in tariffs), which will change government savings, the macroeconomic adjustment will be a compensating change in private savings to finance the fixed aggregate real investment. In the model, any changes in real GDP or real absorption arising from changes in the international terms of trade will go to changes in aggregate real consumption. Given this macro specification, welfare comparisons, which involve calculations of equivalent variation across simulations, are straightforward. A detailed description of the model is given in the Appendix.

\subsection{Dynamic Considerations}

The model captures two types of gains from trade liberalization: (1) there are gains from more efficient utilization of resources, which lead to a one-time permanent increase in GDP and social welfare. (2) There are gains from increases in total factor productivity (TFP) due to technology transfer via expansion of capital and intermediate goods and professional service imports from other countries, especially from advanced industrial countries. Empirical evidences suggest that there is a strong positive feedback from trade expansion to productivity growth. Trade liberalization increases the prevalence of technology transfer as trade barriers are reduced. Firms in the liberalized regions will import more capital goods and technology-intensive goods and professional services as both investment and intermediate inputs from abroad at cheaper prices. Those goods and services incorporate advanced technology from developed countries, and thus stimulate productivity growth in the receiving developing country.

To quantify the first effect, the aggregate productive capital stock is fixed in each region, and the 
region-specific average rental rate adjusts to ensure that regional capital is fully utilized and allocated efficiently across sectors to equate sectoral rental rates. This treatment is common in theoretical work and many CGE models. It essentially assumes a long-run equilibrium, where sectoral capital stocks are able to adjust to changes in market conditions and technology.

To capture the second type of gains, we introduce following equation into our model:

$$
\operatorname{ITFP}_{i r}=1+i m s_{i r} \times\left(\frac{N X_{i r}}{N X_{i r}+V A_{i r}} \times\left[\frac{\sum_{j \in I M} \sum_{s \in R} X_{j s r}}{\sum_{j \in I M} \sum_{s \in R} X O_{j s r}}\right]^{\sigma i p_{i r}}+\frac{V A_{i r}}{N X_{i r}+V A_{i r}}-1\right)
$$

This equation links import-embodied technology transfer (via imports of capital goods, intermediate inputs, and professional services) and total factor productivity. Where ITFP ir is the TFP shift variables in each sector cost function, $i m s_{i r}$ is the share of imported products and services that are embodied with advanced technology used as firms' intermediate inputs in total imports of such products and services at region $r, N X_{i r}$ and $V A_{i r}$ are intermediate inputs and primary factor inputs respectively. $X O_{\text {isr }}$ is the base year trade flows, IM is a subset of $i$, refer to those products embodied with advanced technology. It operates through share parameters and elasticities. An elasticity ( $\sigma \mathrm{ip}_{\text {ir }}$ ) of 0.1 implies that a 10 percent increase in real imports of capital and technology intensive goods would result a no more than 1 percent increase in total factor productivity in that sector depending on the share of imported intermediate inputs in the sector's total imports.

As pointed by Hanel (2000) and Lewis, Robinson, and Wang (1995), while there is fairly widespread agreement that linkage between imports of intermediate inputs and TFP do exist, there is less evidence of the size of the feedback. 3 In our simulation exercises, the elasticities used for developed countries are smaller than the values used for developing countries. We also assume the technology transfer flow only in one direction - from more developed regions to less developed regions.

\section{Structural Information in the Base Year Data}

The CGE model was calibrated around a ten-region, eleven-sector, world Social Accounting Matrix

3 Lewis, Robinson, and Wang (1995) and de Melo and Robinson (1992) specify other trade externalities between exports and TFP. In this model, we only incorporate a link through imports of intermediate and capital goods from developed countries. 
(SAM) estimated for 1995 based on version 4 of the GTAP database (Hertel, 1997). Details of this type of multi-regional SAM and its construction from the GTAP database are described in Wang (1994). Robinson, Cattaneo and El-said (2001) describe how to incorporate and reconcile additional information from a variety of sources into the SAM.

The detailed structural information and the linkage between those service sectors and the rest of the economy are contained in the world SAM and provide the essential data for our model. This section describes the structure of value-added, production costs, inter-industry links between services and other sectors of each region as well as trade dependence among regions. The SAM-based economic data provides an overview of the important role that the service sectors play in the regional economies, and the inter-sector and inter- regional links.

\section{(Insert Table 1 here)}

Table 1 reports GDP, total exports, imports, and the relative size of each of the ten regional economies included in the model. Tables 2 and 3 present the sectoral composition of value-added and service intermediate inputs as a percentage of total production costs for each sector in the ten economies. The United States, EU, and Japan are the three largest economies in the world, and constitute more than 70 percent of world GDP and about 50 percent of international trade.4 Most value-added production activities are concentrated in trade and transport, as well as private and public service sectors (more than 60 percent of GDP) in these advanced economies, while agriculture constitutes less than 3 percent of their GDP. By contrast, ASEAN, China, and especially South Asia, which represent low income developing countries in the model, have large agricultural shares in $\operatorname{GDP}(13,20$, and 29 percent in 1995, respectively).

There are a number of common features across the regional economies: (1) There are relatively large intermediate and durable goods manufacturing sectors across all the economies except South Asia. The three East Asian economies (Japan, Asia NICs, and China) have the highest share, indicating that East Asia is emerging as a major manufacturing center in the world. (2) Trade and transport is

\footnotetext{
4 In our model, all trade data refer to trade with economies outside that region, trade flows within the region were netted out and treated as another source of domestic demand when the 1995 world SAM was constructed from version 4 GTAP database.
} 
the largest or second largest value-added sector in almost all of the ten economies, reflecting its crucial role in virtually all economies.

\section{(Insert table 2 here)}

As indispensable intermediate inputs in all production activities, the cost of various services constitutes a significant portion of total production costs in all sectors across countries (Table 3 ). It is more than 26 percent of agricultural production costs in the United States, about 25 percent of manufacturing production costs in Japan, and 20 percent production costs of intermediate and durables in the EU. The cost share of service inputs in advanced countries such as EU, Japan, and the United States are higher than in developing countries such as China and South Asia. However, intermediate services inputs also constitute 15-20 percent of production costs for manufacturing products even in developing countries such as China and South Asia. Among various services intermediate input, private services (include banking, insurance, business and various professional services), trade and transport (include whole sale, retail and domestic transport services) are most important sectors, constituting more than two thirds of total service cost. The cost share for trade and transport, as basic mean for almost any economic activities, are quite similar in all economies, range 6-8 percent, whereas the cost share of private services varies significantly across countries, and positively correlated with the level of each country's economic development. It took a much higher share in production cost of those developed economies. This input-output, forward link between services and other production sectors is one of the important channels that transmits gains from trade liberalization in the service sectors to the rest of the economy. Such forward links can only be captured in a general equilibrium framework.

\section{(Insert table 3 here)}

Tables 4 and 5 present measures of trade dependence across countries -- the ratios of exports to gross output and imports to total demand at the sectoral level, respectively. Because of their geographical location and small size, the Asia NICs and ASEAN countries have the highest trade dependence, especially for manufacturing products. Other OECD countries (the model region) also rely heavily on international trade: 39 percent of their intermediate manufactures and durable products are absorbed by the world market, and 42 percent of their heavy manufacturing goods demand is 
supplied by other countries. Twenty years of market-oriented economic reform have also caused China to be strongly linked with the world economy, especially its manufacturing sectors. In 1995, China exported more than one third (36 percent) of its labor-intensive output and imported nearly 20 percent of its intermediate and durable goods demand from abroad. The United States, EU, and Japan, as the largest economies in the world, are relatively more self-sufficient. However, at the sectoral level, about 15 percent of their manufacturing intermediates and durable products are exported to the world market. Generally speaking, trade dependence in the services sector is much lower than in other production sectors for most economies, with a few exception for Asia NICs and ASEAN. However, service trade is still significant in absolute amounts, because the service sector is so large, especially in the advanced countries.

\section{(Insert table 4 and 5 here)}

Table 6 presents the share of imports used as intermediate inputs by sector. These shares are very high for most sectors and countries, especially for durables and most service sectors. In the model, we assume that imports from advanced countries embody advanced technologies and their use in production will increase productivity for all factors in the importing country. This trade-productivity linkage is easily seen for intermediate and durable products such as chemicals and machinery, but the link is also probably valid for private services such as financial and accounting services. The presence of a banking or retailing facilities from advanced countries will very likely improve the efficiency of the financial and trade sector in the host country, and hence increase total factor productivity, especially in sectors with heavy demand for such services as intermediate inputs.

\section{(Insert table 6 here)}

In addition, services trade has a dual function in an economy. First, it contributes to trade directly, such as construction firms undertaking construction projects in other countries. Second, services are traded internationally as part of merchandise trade. Trade and transport services (wholesaling, retailing, and transport services) are an obvious example.

The sectoral pattern and degree of protection are very important in determining the impact of trade liberalization. The larger and more varied the initial sectoral distortions, the greater is the impact from an policy changes. For this analysis, the impact of service sector trade liberalization largely 
depends on the structure of existing trade barriers captured by the estimated 1995 world SAM. The initial sector import protection rates as a percentage of f.o.b. value in each region are presented in Table 7 .

\section{(Insert table 7 here)}

These import protection rates show that there is substantial variation across commodity groups and across regions. Food and agricultural sectors are highly protected, especially in Japan and Asia NICs. The high protection rates reflect high tariffs and many non-tariff barriers, such as import licensing and quotas, in those countries. The average protection rates in other merchandise sectors are generally lower, especially for natural resource based products in the industrial countries. The rates of import protection are generally higher in China and South Asia than in other regions, especially for the manufacturing sectors.

The tariff equivalents of protection in services trade is adopted from data developed for the Australian IC95 model (Dee, 1998), which were taken in turn from Brown et al. (1995) and work by

Hoekman. ${ }^{5}$ These protection rates are essentially "guesstimates" according to Brown and Dee. They are, however, the only estimates available to us when this analysis was conducted, and provide an initial basis for analyzing the impact of service trade liberalization.

The GTAP database provides detailed information on the structure of the regional economies, on the links between the service sectors and the rest of the economy, and on trade links among the major regions in the world. The multi-country CGE model is based on this data and provides a consistent framework for tracing the impact of trade liberalization and changes in the service sectors across the world economy.

\section{Simulation Design}

We seek to analyze the consequences of service sector trade liberalization and technology changes in

5 Hoekman (1995) used the presence or absence of offers made during the GATS agreement as revealed preference indicator of the protection level for each type of barriers to service trade, then tariff equivalents was assigned to each protection measure so that a weighted average protection level for each service sector could be generated (200 percent for measure judged to be prohibitive). 
international transport costs, and compare them with non-service trade liberalization. We did one scenario in which transport costs are lowered and four trade-liberalization scenarios (five scenarios in all), under three different assumptions about technology links from advanced to less developed countries. The fifteen experiments are described in Table 8.

\section{(Insert table 8 here)}

In the first scenario, we reduce the international transportation margin by 50 percent across all bilateral trade flows included in the model. The second scenario is trade liberalization in the nonservice sectors (50 percent cut in protection for food, agriculture, and natural resource based sectors; and elimination of protection in all manufacturing sectors). The third scenario liberalizes service sector trade (a 50 percent cut in service sector protection). The last two are combinations of the first three. In the forth scenario, trade liberalization in both services and non-service sectors are combined. The fifth and final scenario adds technology change in international shipping and trade liberalization together with trade liberalization in scenario 4.

For each of the five scenarios, import-embodied technology transfer are assumed via two alternative channels: (1) imported durable products used as intermediate inputs; and (2) imported private services and trade and transport as intermediate inputs. An additional simulation in each scenario was done assuming no import-embodied technology transfer, which provides a benchmark for comparisons. In all, 15 simulations were conducted.

\section{Major Simulation Results and Analysis}

Tables 9 to 11 summarize the major aggregate economy-wide effects (in percent changes from the base) for the 15 simulations: changes in social welfare measured as Hicksian equivalent variation (EV), total exports, and total factor productivity (TFP). Three empirical results stand out.

First, the efficiency gain from trade liberalization in the manufacturing sectors is not large for most countries and the world as a whole. A 100 percent elimination of protection in all manufacturing sectors generates less gain in real GDP than a 50\% percent cut in the protection level in one service sector for most economies in the model. Asia is the notable exception. When terms-of-trade effects are taken into account, only Japan and Asia NICs still gain more from the non-service sector trade liberalization experiments (compare the results of E01 with E04 in table 9). The welfare gain for the 
world as a whole from a 50\% percent cut of protection in the service sectors is 5 times larger than that from non-service sector trade liberalization, although the trade impacts are larger in the case of non-service sector trade liberalization for Japan, Asia NICs, and other developing countries. The reason for this result is that protection levels in manufacturing sectors are low in the industrial countries after the completion of the Uruguay Round (Table 7) and services constitute the largest share of economic activity for most countries in the model.

Second, the gain in TFP from import-embodied technology transfer has a stronger impact on social welfare than an expansion in trade. When trade-TFP links are assumed, the increases in trade (both exports and imports) are relatively small, while the increases in GDP and social welfare are relatively large (compare the difference between E04, EM4, and ES4 in tables 9 with those in tables 10). This result is because the growth in TFP also enhances the efficiency of the non-traded sector, which is much larger than the traded sectors for most countries in the world.

Finally, the productivity gain from import-embodied technology spillover is much stronger when it works through service sector imports for developed countries, while for developing countries the effect is larger when it works through imports of intermediate and durable goods (Table 11). In the developed countries, imports of services used as intermediate inputs are more important than in developing countries (Table 3 ).

\section{(Insert table 9,10 and 11 here)}

Table 12 presents the impact of a 50 percent reduction in international shipping margins on each region's structure of production and exports. Cutting the transportation margin reduces the cost of delivering products to consumers and boosts merchandise exports in all sectors for almost every region as a results of more resources flow from non-traded sectors towards the traded sectors. It also reduces the demand for international shipping, inducing a reduction in each region's gross output from the trade and transport sector, which in turn releases factors of production to be used in other economic activities (according to each region's comparative advantage). Agricultural production expands in the United States, but shrinks in Japan, EU, and Asia NICs. Production of labor-intensive consumer goods increases in China, ASEAN, and South Asia, but decreases in Japan, EU, and the United States. At the same time, capital-intensive durable goods production increases in all OECD 
countries and Asia NICs, but declines in China, South Asia, and Latin America. Imposing tradeproductivity links increases production in all sectors, but manufacturing products benefit relatively more than other products.

\section{(Insert table 12 here)}

Tables 13 reports the results from a 50 percent cut in service trade restrictions on each region's production, exports and TFP growth by sectors. As protection levels in the service sectors are reduced, each region reallocates resources to more profitable sectors according to their comparative advantage. For example, the United States increases production of agriculture, processed food, and all service sectors, but reduces output of manufacturing. Japan reduces production in agricultural and natural resource related sectors. While the scenario cuts import protection in the service sectors, sector output is not affected uniformly across the regions. Output of private services declines in Japan, other OECD, Asia NICs, Latin American, and rest of the world, while it expands elsewhere. There is two-way trade in services in most regions with significant imports and exports (tables 4 and 5). The net impact of trade liberalization depends on these trade ratios and on elasticities of substitution (import demand). There is also a close link between services trade and merchandise trade, although the pattern of the relationship are different across regions. In the United States, Asia NICs, China, and ASAEN the expansion trade in services leads to declines in merchandise exports, but in EU, Japan, other OECD and Latin America, exports of goods expand along with exports in services. Whether service trade is substitute for merchandise trade or complement it depends on both the backward and forward linkage between services and other sectors.

\section{(Insert table 13 here)}

Comparing changes in sector specific TFP growth in EM2 and ES2, it is easy to find the different pattern of TFP growth due to service sector trade liberalization under the two different assumptions concerning import-embodied technology transfer. When advanced technology comes through imports of intermediate and durable manufactures, service sector liberalization only has

limited impact on each region's TFP growth. Such growth is relatively concentrated in the intermediate and durable sectors. However, if the transfer channel is assumed via imported service intermediate inputs, the impacts are quite significant and spread to more sectors through forward 
linkages.

\section{(Insert table 14 here)}

Tables 14 and 15 present the impact of total trade liberalization plus reduction in international shipping cost on each region's production and exports under alternative assumption about import embodied technology transfer. Three interesting points can be drawn from these results. First, services production and exports expand in almost all sectors across the world, with few exceptions, as results of a comprehensive liberalization in trade, indicating the crucial role of services in all economic activities. While the change in production and exports in non-services sector are not uniformly distribute across regions. Production of labor-intensive consumer good declines in all OECD countries, but expands dramatically in all developing counties. In the meantime, capitalintensive durable goods production contracts in all developing countries, but increase in OECD countries and Asia NICs. Production in agriculture and natural resource based sectors decline in Japan and Asia NICs, but increase elsewhere in the world. Such an adjustment pattern seems consistent with each regions comparative advantage by intuition. Second, each sector's liberalization re-enforces each other through input-output relations across regions. There are significant gains in production and exports for services sector because liberalization in merchandise trade. For example, exports of private services increase additional 7 percent in the United States because of non-service sector liberalization (compare experiment E04 in table 15 and experiment E02 in table 13). Finally, the degree of structural adjustment after trade liberalization in developing countries may be overstated without considering the impact of import embodied technology transfer on TFP growth (table 15, compare percent change in production of intermediate and durable goods in experiment E04 and EM4).

\section{(Insert table 15 here)}

\section{Conclusions and Direction for further Work}

Service sector trade liberalization not only directly affects world service production and trade, but also has significant implications for other sectors in the economy. The major channel of the impact is through international transportation margins and forward-linkages through inter-industry inputoutput relations. The data indicate that, while trade is a relatively small share of output in the service 
sectors in most regions, the sectors are very large and the protection levels are very high. The recent focus on trade in services in world trade negotiations certainly seems appropriate $\bullet \bullet \bullet$ there are large numbers involved and potentially significant improvements in welfare from trade liberalization. There are also potential tradeoffs between gains from liberalizing trade in services and manufacturing that should provide a basis for negotiations between developing and developed countries. Developed countries gain relatively more from increasing exports of services to developing countries, while developing countries potentially gain more from increased access to developed country markets for their exports of manufactures.

When the international shipping margin is reduced, less production resources will be used to deliver products to consumers through international trade. Resources are released from services for use in other economic activities. When trade barriers in the service sectors are reduced, service production and exports expand, thus increasing the demand for other products used as intermediate inputs (backward linkages). At the same time, through forward linkages, the fall in service prices reduces production costs in sectors that use services as an intermediate input, which is significant for many sectors across the world.

Another important channel through which trade liberalization affects the economy is TFP growth induced from intermediate inputs, capital goods, and professional services imported into developing countries from advanced countries. Our empirical results indicate that such links are potentially very significant. The nature of these productivity links, however, needs much more study. The stylized links we incorporated in our model really represents a first step in understanding how tradeproductivity links might work during service sector trade liberalization.

\section{References}

Brooke, Anthony, David Kendrick and Alexander Meeraus (1988) GAMS: a User's Guide, (New York, The Scientific Press). 
Brown, Drusilla, Alan Deardorff, Alan Fox, and Robert Stern (1995) Computational Analysis of Goods and services Liberalization in Uruguay Round, in: Will Martin and Alan Winters (eds) The Uruguay Round and the Developing Economies, World Bank Discussion Paper 307. (Washington DC, The World Bank) .

Deardorff, Alan V and Robert M. Stern (1990) computational Analysis of Gobal Trading Arrangement, (Ann Arbor, University of Michigan Press).

Devarajan, Shantayanan, Jeffrey D. Lewis and Sherman Robinson (1990) Policy Lesson From Trade-Focused, Two-Sector Models, Journal of policy modeling 12(4), pp. 625-657.

Devarajan, Shantayanan, Jeffrey D. Lewis and Sherman Robinson (1993) External Shocks, Purchasing Power Parity, and the Equilibrium Real Exchange Rate, The World Bank economic Review 7(1), pp. 45-63.

Dee, Philippa (1998) The Comprehensiveness of APEC's Free Trade Commitment in: The Economic Implications of Liberalizing APEC Tariff and Non-tariff Barriers to Trade, Publication 3101, U.S. International Trade Commission.

De Melo, J. and Robinson Sherman (1992) Productivity and externalities: Models of export-led growth, Journal of International Trade and Economic Development, Vol. 1, pp. 41- 68.

de Melo, J. and David Tarr (1992) A General Equilibrium Analysis of US Foreign Trade Policy, (Cambridge, Massachusetts, The MIT Press).

Hertel, Thomas W. ed. (1997) Global Trade Analysis: Modeling and Applications, (Cambridge, Cambridge University Press).

Hanel, Peter (2000) R\&D, Interindustry and International Technology Spillovers and the Total Factor Productivity Growth of Manufacturing Industries in Canada, 1974-1989, Economic System Research, Vol. 12(3), pp. 345-61.

Hoekman Bernard (1995) Assessing the General Agreement on Trade in Services, in: Will Martin and Alan Winters (eds) The Uruguay Round and the Developing Economies, World Bank Discussion Paper 307. (Washington DC, The World Bank).

Howe, H. (1975) Development of the Extended Linear Expenditure System from Simple Savings 
Assumptions, European Economic Review 6, pp. 305-310.

Lewis, Jeffrey D. and Sherman Robinson (1996) Partners or Predators? The Impact of Regional Trade Liberalization on Indonesia, Policy Research Working Paper No. 1626, (Washington DC, The World Bank).

Lewis, Jeffrey D., Sherman Robinson, and Zhi Wang (1995) Beyond the Uruguay Round: The Implication of an Asian Free Trade Area, China Economic Review - An International Journal 7 , pp. 35-90.

Luanga, Mukela and Wusheng Yu (1999) Trade in Services Data: Data Source, Classification, Evaluation, and Construction, Working paper, GTAP Center, Purdue University.

Marcus Noland, Li-Gang Liu, Sherman Robinson and Zhi Wang (1998) Global Economic Effects of the Asian Currency Devaluations (Washington DC, Institute of International Economics).

Robinson, Sherman, Andrea Cattaneo and Moataz El-Said (2001) Updating and Estimating a Social Accounting Matrix Using Cross Entropy Methods, Economic System Research, Vol. 13(1), pp. $47-64$.

Wang, Zhi (1994) The Impact of Economic Integration Among Taiwan, Hong Kong and ChinaA Computable General Equilibrium Analysis, Department of Applied Economics, Ph.D

Dissertation, University of Minnesota.

Wang, Zhi and Jean Kinsey (1994) Consumption and Saving Behavior under Strict and Partial Rationing, China Economic Review - An International Journal 5, pp. 83-100.

Wang, Zhi (1997). The Impact of China and Taiwan Joining the World Trade Organization on U.S. and World Agricultural Trade: A computable General Equilibrium Analysis, Technical Bulletin, No. 1858, U.S. Department of Agriculture, Economic Research Service.

Whalley, J. (1985) Trade Liberalization among Major World Trading Areas, (Cambridge, Massachusetts, The MIT Press).

Varian, Hal R. (1984) Microeconomic Analysis. Second edition, (New York,W.W. Norton \& Company). 
Table 1 Size of the Economy by Region

\begin{tabular}{|c|c|c|c|c|c|c|c|c|c|c|c|}
\hline & $\begin{array}{l}\text { United } \\
\text { States }\end{array}$ & EU15 & Japan & $\begin{array}{l}\text { Other } \\
\text { OECD }\end{array}$ & $\begin{array}{l}\text { Asia } \\
\text { NICs }\end{array}$ & China & ASEAN & $\begin{array}{l}\text { South } \\
\text { Asia }\end{array}$ & $\begin{array}{l}\text { Latin } \\
\text { America }\end{array}$ & $\begin{array}{l}\text { Rest of } \\
\text { the World }\end{array}$ & $\begin{array}{l}\text { World } \\
\text { Total }\end{array}$ \\
\hline GDP (Billion US\$) & 7,150 & 8,266 & 5,109 & 1,735 & 911 & 713 & 538 & 438 & 1,389 & 2,280 & 28,527 \\
\hline Exports (Billion US\$) & 717.8 & 895.1 & 484.2 & 494.4 & 405.2 & 210.5 & 217.7 & 55.6 & 142.8 & 457.9 & 4081.3 \\
\hline Imports (Billion US\$) & 883.2 & 883.3 & 435.2 & 462.1 & 443.7 & 167.3 & 236.5 & 65.1 & 169.8 & 498.5 & 4244.8 \\
\hline GDP as $\%$ of World & 25.1 & 29.0 & 17.9 & 6.1 & 3.2 & 2.5 & 1.9 & 1.5 & 4.9 & 8.0 & 100.0 \\
\hline Exports as $\%$ of World & 17.6 & 21.9 & 11.9 & 12.1 & 9.9 & 5.2 & 5.3 & 1.4 & 3.5 & 11.2 & 100.0 \\
\hline Imports as $\%$ of World & 20.8 & 20.8 & 10.3 & 10.9 & 10.5 & 3.9 & 5.6 & 1.5 & 4.0 & 11.7 & 100.0 \\
\hline Balance of trade (Billion US\$) & -131.4 & 46.4 & 67.4 & 49.7 & -20.3 & 50.1 & -9.8 & -7.1 & -20.4 & -24.5 & 0.0 \\
\hline
\end{tabular}

Table 2 Sector Composition of Value-added by Region

\begin{tabular}{|c|c|c|c|c|c|c|c|c|c|c|}
\hline & $\begin{array}{l}\text { United } \\
\text { States }\end{array}$ & EU15 & Japan & $\begin{array}{l}\text { Other } \\
\text { OECD }\end{array}$ & $\begin{array}{l}\text { Asia } \\
\text { NICs }\end{array}$ & China & ASEAN & $\begin{array}{l}\text { South } \\
\text { Asia }\end{array}$ & $\begin{array}{l}\text { Latin } \\
\text { America }\end{array}$ & $\begin{array}{l}\text { Rest of } \\
\text { the World }\end{array}$ \\
\hline Agriculture & 1.3 & 2.3 & 2.5 & 3.6 & 5.8 & 20.3 & 13.1 & 28.8 & 10.5 & 9.6 \\
\hline Processed food & 2.7 & 3.0 & 2.6 & 3.2 & 1.8 & 2.1 & 6.3 & 1.7 & 5.4 & 3.9 \\
\hline Resource based & 2.2 & 2.2 & 2.0 & 6.0 & 2.8 & 11.6 & 11.6 & 7.1 & 4.8 & 12.9 \\
\hline Consumer goods & 4.2 & 4.4 & 4.1 & 4.7 & 5.0 & 5.8 & 6.2 & 6.5 & 6.7 & 5.1 \\
\hline Intermediate \& durable & 15.6 & 16.5 & 18.1 & 13.4 & 19.8 & 18.3 & 16.2 & 8.3 & 13.6 & 12.9 \\
\hline Utility & 2.3 & 1.9 & 4.5 & 3.1 & 3.6 & 3.5 & 1.9 & 3.5 & 3.6 & 4.2 \\
\hline Construction & 6.4 & 5.9 & 8.1 & 5.5 & 6.5 & 5.9 & 6.2 & 5.0 & 5.5 & 5.3 \\
\hline Trade and transport & 20.2 & 18.2 & 22.5 & 24.3 & 23.5 & 17.4 & 21.2 & 17.0 & 15.4 & 18.7 \\
\hline Private services & 22.3 & 23.6 & 27.1 & 15.7 & 12.7 & 6.4 & 8.0 & 1.6 & 20.6 & 12.8 \\
\hline Public services & 17.3 & 15.9 & 8.6 & 12.4 & 13.7 & 6.6 & 6.3 & 13.7 & 11.0 & 11.9 \\
\hline Housing & 5.5 & 6.0 & 0.0 & 8.2 & 4.9 & 2.0 & 3.1 & 6.8 & 2.9 & 2.9 \\
\hline Total & 100.0 & 100.0 & 100.0 & 100.0 & 100.0 & 100.0 & 100.0 & 100.0 & 100.0 & 100.0 \\
\hline
\end{tabular}


Table 3 Service Inputs as Percentage of Total Production Cost by Sector across Regions

\begin{tabular}{|c|c|c|c|c|c|c|c|c|c|c|}
\hline & $\begin{array}{l}\text { United } \\
\text { States }\end{array}$ & EU15 & Japan & $\begin{array}{l}\text { Other } \\
\text { OECD }\end{array}$ & $\begin{array}{l}\text { Asia } \\
\text { NICs }\end{array}$ & China & ASEAN & $\begin{array}{c}\text { South } \\
\text { Asia }\end{array}$ & $\begin{array}{c}\text { Latin } \\
\text { America }\end{array}$ & $\begin{array}{l}\text { Rest of } \\
\text { the World }\end{array}$ \\
\hline \multicolumn{11}{|c|}{ Total services } \\
\hline Agriculture & 26.3 & 15.5 & 14.4 & 21.8 & 8.1 & 6.5 & 4.5 & 8.3 & 6.6 & 9.4 \\
\hline Processed food & 14.1 & 18.7 & 17.5 & 17.2 & 9.8 & 10.2 & 10.1 & 17.2 & 12.2 & 13.8 \\
\hline Resource based & 20.2 & 22.9 & 26.3 & 24.8 & 17.0 & 19.9 & 9.9 & 13.3 & 14.8 & 15.3 \\
\hline Consumer goods & 15.1 & 20.4 & 22.7 & 18.3 & 16.7 & 15.0 & 12.1 & 20.3 & 13.2 & 15.5 \\
\hline Intermediate \& durable & 15.7 & 19.6 & 25.4 & 16.1 & 14.0 & 17.4 & 8.9 & 16.3 & 13.2 & 17.0 \\
\hline Utility & 27.3 & 26.7 & 23.3 & 18.3 & 14.2 & 16.5 & 21.0 & 44.5 & 33.7 & 22.8 \\
\hline Construction & 22.2 & 28.0 & 22.5 & 21.1 & 16.8 & 13.7 & 15.3 & 16.4 & 15.8 & 19.0 \\
\hline Trade and transport & 30.1 & 31.2 & 28.1 & 27.3 & 38.0 & 22.3 & 22.6 & 18.5 & 24.8 & 23.7 \\
\hline Private services & 35.6 & 42.9 & 20.5 & 36.3 & 30.7 & 29.8 & 20.7 & 10.5 & 16.4 & 23.3 \\
\hline Public services & 14.6 & 28.3 & 8.2 & 26.0 & 18.8 & 25.4 & 13.2 & 11.2 & 19.2 & 21.3 \\
\hline Housing & 15.8 & 19.7 & 15.9 & 15.4 & 22.7 & 10.5 & 15.6 & 10.8 & 19.0 & 10.6 \\
\hline Total & 23.4 & 28.6 & 22.8 & 23.4 & 20.8 & 17.0 & 13.4 & 16.0 & 16.3 & 18.2 \\
\hline \multicolumn{11}{|c|}{ Trade and transport } \\
\hline Agriculture & 7.5 & 5.6 & 7.0 & 10.0 & 2.9 & 3.4 & 2.9 & 4.1 & 3.1 & 4.0 \\
\hline Processed food & 7.5 & 6.5 & 10.2 & 9.2 & 5.1 & 5.3 & 5.8 & 10.5 & 5.7 & 7.2 \\
\hline Resource based & 5.3 & 9.3 & 11.7 & 8.3 & 5.9 & 7.2 & 5.1 & 4.4 & 4.9 & 5.1 \\
\hline Consumer goods & 7.0 & 7.0 & 11.4 & 9.7 & 7.8 & 10.0 & 7.3 & 8.5 & 5.8 & 7.2 \\
\hline Intermediate \& durable & 7.6 & 6.6 & 10.0 & 7.4 & 5.9 & 8.8 & 5.5 & 6.7 & 5.2 & 6.7 \\
\hline Utility & 4.0 & 2.8 & 5.1 & 3.4 & 2.7 & 8.5 & 6.7 & 6.6 & 2.6 & 4.3 \\
\hline Construction & 9.9 & 5.8 & 9.9 & 7.9 & 7.2 & 11.3 & 11.9 & 11.0 & 6.7 & 8.2 \\
\hline Trade and transport & 10.6 & 16.6 & 9.4 & 12.5 & 24.2 & 12.3 & 9.4 & 9.2 & 9.9 & 10.1 \\
\hline Private services & 5.7 & 4.2 & 5.1 & 6.6 & 4.6 & 10.5 & 4.6 & 2.9 & 2.8 & 5.3 \\
\hline Public services & 2.9 & 3.4 & 2.9 & 6.4 & 4.4 & 13.8 & 5.1 & 3.0 & 4.6 & 5.4 \\
\hline Housing & 0.1 & 0.3 & 2.9 & 0.4 & 0.2 & 4.3 & 5.9 & 2.8 & 1.2 & 1.1 \\
\hline Total & 6.9 & 6.9 & 8.4 & 8.0 & 8.9 & 8.9 & 6.7 & 6.5 & 5.4 & 6.6 \\
\hline \multicolumn{11}{|c|}{ Private services } \\
\hline Agriculture & 16.5 & 5.9 & 6.4 & 6.8 & 4.3 & 2.4 & 1.0 & 0.1 & 3.1 & 2.5 \\
\hline Processed food & 4.8 & 9.5 & 5.4 & 5.8 & 3.2 & 2.9 & 2.9 & 0.5 & 5.2 & 3.9 \\
\hline Resource based & 10.4 & 8.7 & 10.2 & 9.1 & 4.8 & 3.2 & 2.6 & 0.2 & 6.7 & 4.3 \\
\hline Consumer goods & 5.3 & 10.4 & 7.9 & 5.2 & 5.3 & 2.9 & 2.3 & 0.4 & 5.8 & 4.3 \\
\hline Intermediate \& durable & 5.3 & 10.1 & 10.1 & 5.9 & 4.7 & 4.1 & 1.7 & 0.3 & 6.2 & 5.2 \\
\hline Utility & 5.3 & 8.6 & 12.4 & 4.0 & 3.8 & 2.0 & 1.7 & 0.1 & 10.9 & 2.6 \\
\hline Construction & 11.9 & 11.7 & 11.1 & 10.9 & 8.1 & 1.2 & 2.7 & 0.2 & 5.6 & 5.3 \\
\hline Trade and transport & 15.4 & 9.9 & 14.9 & 10.6 & 9.7 & 5.2 & 8.1 & 0.5 & 12.0 & 8.7 \\
\hline Private services & 26.0 & 33.5 & 11.6 & 25.2 & 20.1 & 8.2 & 10.9 & 0.3 & 11.7 & 13.2 \\
\hline Public services & 7.9 & 8.6 & 3.4 & 7.9 & 5.4 & 4.5 & 3.8 & 0.3 & 11.3 & 5.0 \\
\hline Housing & 10.0 & 8.8 & 2.5 & 6.3 & 7.5 & 2.2 & 4.9 & 0.3 & 5.7 & 3.8 \\
\hline Total & 12.9 & 15.2 & 10.6 & 10.3 & 7.5 & 3.7 & 3.9 & 0.3 & 8.0 & 5.9 \\
\hline
\end{tabular}


Table 4 Sectoral Export Dependence by Region

\begin{tabular}{lllllllllll}
\hline & $\begin{array}{l}\text { United } \\
\text { States }\end{array}$ & EU15 & Japan & $\begin{array}{l}\text { Other } \\
\text { OECD }\end{array}$ & $\begin{array}{l}\text { Asia } \\
\text { NICs }\end{array}$ & China & ASEAN & $\begin{array}{l}\text { South } \\
\text { Asia }\end{array}$ & $\begin{array}{l}\text { Latin } \\
\text { America }\end{array}$ & $\begin{array}{l}\text { Rest of } \\
\text { the World }\end{array}$ \\
\hline Agriculture & 13.7 & 3.7 & 0.2 & 20.2 & 2.8 & 2.4 & 12.5 & 2.0 & 10.4 & 6.7 \\
Processed food & 5.2 & 4.9 & 0.3 & 14.0 & 6.2 & 6.9 & 18.2 & 11.8 & 8.4 & 4.7 \\
Resource based & 5.7 & 9.0 & 2.7 & 37.1 & 5.9 & 5.7 & 28.3 & 20.4 & 18.0 & 34.9 \\
Consumer goods & 6.8 & 9.4 & 2.3 & 27.7 & 35.1 & 36.4 & 46.5 & 26.1 & 8.2 & 16.2 \\
Intermediate \& durable & 16.3 & 14.3 & 16.5 & 38.9 & 37.6 & 18.3 & 47.2 & 8.1 & 6.5 & 14.5 \\
Utility & 0.0 & 0.5 & 0.0 & 2.0 & 0.2 & 0.7 & 0.0 & 0.0 & 0.0 & 0.2 \\
Construction & 0.0 & 0.8 & 0.0 & 0.2 & 0.8 & 0.0 & 0.4 & 0.0 & 0.0 & 1.9 \\
Trade and transport & 3.4 & 3.6 & 2.2 & 7.9 & 18.7 & 4.0 & 13.3 & 2.2 & 4.0 & 8.6 \\
Private services & 3.2 & 2.2 & 0.9 & 3.3 & 5.3 & 7.3 & 13.1 & 6.8 & 1.3 & 3.7 \\
Public services & 1.7 & 1.5 & 0.1 & 3.9 & 3.3 & 1.7 & 1.4 & 7.8 & 3.8 & 3.7 \\
Housing & 0.0 & 0.0 & 0.0 & 0.0 & 0.0 & 0.0 & 0.0 & 0.0 & 0.0 & 0.0 \\
Total & 5.9 & 5.5 & 5.0 & 16.0 & 19.3 & 11.7 & 22.8 & 7.6 & 5.6 & 10.8 \\
\hline
\end{tabular}

\section{Table 5 Sectoral Import Dependence by Region}

\begin{tabular}{lllllllllll}
\hline & $\begin{array}{l}\text { United } \\
\text { States }\end{array}$ & EU15 & Japan & $\begin{array}{l}\text { Other } \\
\text { OECD }\end{array}$ & $\begin{array}{l}\text { Asia } \\
\text { NICs }\end{array}$ & China & ASEAN & $\begin{array}{l}\text { South } \\
\text { Asia }\end{array}$ & $\begin{array}{l}\text { Latin } \\
\text { America }\end{array}$ & $\begin{array}{l}\text { Rest of } \\
\text { The World }\end{array}$ \\
\hline Agriculture & 7.2 & 11.4 & 8.3 & 11.2 & 15.8 & 3.9 & 8.1 & 2.1 & 2.6 & 6.0 \\
Processed food & 4.2 & 3.8 & 5.4 & 8.5 & 11.6 & 6.1 & 7.9 & 8.5 & 2.7 & 12.5 \\
Resource based & 21.8 & 23.8 & 23.8 & 15.4 & 42.7 & 4.4 & 18.2 & 25.9 & 7.1 & 5.4 \\
Consumer goods & 14.9 & 11.8 & 8.6 & 25.8 & 26.4 & 17.1 & 21.8 & 6.9 & 7.2 & 19.2 \\
Intermediate \& durable & 20.0 & 11.4 & 6.7 & 42.2 & 39.7 & 18.8 & 58.2 & 22.8 & 16.7 & 25.6 \\
Utility & 0.3 & 0.3 & 0.0 & 1.8 & 1.0 & 0.2 & 0.0 & 0.0 & 0.0 & 0.1 \\
Construction & 0.0 & 0.2 & 0.0 & 0.6 & 1.6 & 0.3 & 5.1 & 0.0 & 2.0 & 0.8 \\
Trade and transport & 2.7 & 4.0 & 4.6 & 7.1 & 7.0 & 4.8 & 11.2 & 6.2 & 5.8 & 10.3 \\
Private services & 2.1 & 1.7 & 1.3 & 5.5 & 12.0 & 5.4 & 15.7 & 2.2 & 1.9 & 5.8 \\
Public services & 1.1 & 2.0 & 0.1 & 2.8 & 7.9 & 1.2 & 13.4 & 5.2 & 1.4 & 2.7 \\
Housing & 0.0 & 0.0 & 0.0 & 0.0 & 0.0 & 0.0 & 0.0 & 0.0 & 0.0 & 0.0 \\
Total & 7.2 & 5.5 & 4.5 & 15.2 & 20.9 & 9.5 & 24.3 & 8.8 & 6.6 & 11.7 \\
\hline
\end{tabular}

Table 6 Percent of Imports Used as Intermediate Inputs

\begin{tabular}{|c|c|c|c|c|c|c|c|c|c|c|}
\hline & $\begin{array}{l}\text { United } \\
\text { States }\end{array}$ & EU15 & Japan & $\begin{array}{l}\text { Other } \\
\text { OECD }\end{array}$ & $\begin{array}{l}\text { Asia } \\
\text { NICs }\end{array}$ & China & ASEAN & $\begin{array}{l}\text { South } \\
\text { Asia }\end{array}$ & $\begin{array}{l}\text { Latin } \\
\text { America }\end{array}$ & $\begin{array}{l}\text { Rest of } \\
\text { The World }\end{array}$ \\
\hline Agriculture & 56.2 & 63.6 & 96.7 & 54.7 & 79.4 & 67.7 & 75.2 & 45.9 & 76.7 & 62.6 \\
\hline Processed food & 44.8 & 43.5 & 72.5 & 43.7 & 46.7 & 53.3 & 40.7 & 25.0 & 58.2 & 32.6 \\
\hline Resource based & 95.6 & 91.9 & 98.5 & 95.2 & 95.1 & 97.7 & 68.6 & 96.0 & 92.7 & 91.6 \\
\hline Consumer goods & 36.6 & 51.4 & 47.4 & 50.6 & 57.4 & 75.5 & 68.4 & 57.8 & 68.1 & 54.6 \\
\hline Intermediate \& durable & 72.6 & 77.3 & 90.3 & 81.8 & 92.8 & 94.6 & 88.5 & 85.5 & 85.0 & 77.5 \\
\hline Utility & 50.9 & 83.4 & 74.0 & 67.5 & 90.6 & 17.9 & 91.9 & 80.9 & & \\
\hline Construction & 0.7 & 98.6 & 74.0 & 99.9 & 98.6 & 38.4 & 3.6 & 25.0 & 27.4 & 94.5 \\
\hline Trade and transport & 53.2 & 60.9 & 77.8 & 59.5 & 77.9 & 87.0 & 16.4 & 63.9 & 57.5 & 58.9 \\
\hline Private services & 50.5 & 88.6 & 90.8 & 76.9 & 80.5 & 32.5 & 38.8 & 29.0 & 64.9 & 69.9 \\
\hline Public services & 51.0 & 65.0 & 90.0 & 60.1 & 47.8 & 53.7 & 7.5 & 25.3 & 11.6 & 49.6 \\
\hline
\end{tabular}


Table 7 Sectoral Import Protection Rate by Region

\begin{tabular}{|c|c|c|c|c|c|c|c|c|c|c|}
\hline & $\begin{array}{l}\text { United } \\
\text { States }\end{array}$ & EU15 & Japan & $\begin{array}{l}\text { Other } \\
\text { OECD }\end{array}$ & $\begin{array}{l}\text { Asia } \\
\text { NICs }\end{array}$ & China & ASEAN & $\begin{array}{l}\text { South } \\
\text { Asia }\end{array}$ & $\begin{array}{l}\text { Latin } \\
\text { America }\end{array}$ & $\begin{array}{l}\text { Rest of } \\
\text { the World }\end{array}$ \\
\hline Agriculture & 4.6 & 10.3 & 117.3 & 21.3 & 40.4 & 6.9 & 28.3 & 29.9 & 1.7 & 11.3 \\
\hline Processed food & 9.8 & 26.1 & 30.8 & 25.6 & 18.5 & 17.2 & 38.4 & 55.9 & 9.6 & 24.6 \\
\hline Resource based & 0.8 & 0.4 & 0.5 & 1.7 & 2.7 & 8.8 & 5.0 & 12.6 & 11.6 & 12.8 \\
\hline Consumer goods & 6.6 & 6.1 & 4.6 & 4.9 & 3.0 & 47.3 & 16.0 & 64.7 & 15.3 & 19.1 \\
\hline Intermediate and durable & 1.9 & 3.5 & 1.0 & 2.5 & 4.1 & 25.0 & 12.3 & 58.1 & 12.3 & 12.5 \\
\hline Utility & 0.0 & 0.0 & 0.0 & 0.0 & 0.0 & 0.1 & 0.0 & 0.0 & 0.0 & 0.3 \\
\hline Construction & 0.0 & 99.4 & 0.0 & 73.6 & 44.3 & 37.6 & 37.4 & 0.0 & 102.2 & 109.2 \\
\hline Trade and transport & 69.4 & 95.8 & 65.7 & 81.5 & 47.0 & 44.2 & 40.6 & 108.8 & 108.5 & 107.3 \\
\hline Private services & 70.8 & 101.6 & 67.5 & 74.1 & 47.6 & 40.5 & 40.8 & 107.9 & 107.6 & 110.2 \\
\hline Public services & 71.0 & 101.2 & 66.7 & 80.4 & 51.3 & 42.7 & 43.1 & 106.7 & 104.3 & 108.9 \\
\hline Housing & 0.0 & 0.0 & 0.0 & 0.0 & 0.0 & 0.0 & 0.0 & 0.0 & 0.0 & 0.0 \\
\hline Total & 12.6 & 26.6 & 25.0 & 16.3 & 12.0 & 28.5 & 17.9 & 57.1 & 30.6 & 33.4 \\
\hline
\end{tabular}

\section{Table 8 Experiment Design}

Import-embodied technology transfer

\begin{tabular}{|c|c|c|c|}
\hline Scenarios & Not assumed & $\begin{array}{l}\text { Via intermediates } \\
\text { durable goods }\end{array}$ & $\begin{array}{l}\text { Via the two service } \\
\text { sectors }\end{array}$ \\
\hline $\begin{array}{l}\text { A Technology change in international transport: } \\
50 \% \text { cut in cost of international trade }\end{array}$ & E00 & EM0 & ES0 \\
\hline $\begin{array}{l}\text { B. Non-service sector liberalization: } 50 \% \text { cut in } \\
\text { food \& agriculture, natural resource; } 100 \% \text { cut in } \\
\text { manufacture }\end{array}$ & E01 & EM1 & ES1 \\
\hline $\begin{array}{l}\text { C. Service sector liberalization: } 50 \% \text { cut in all } \\
\text { service sectors }\end{array}$ & E02 & EM2 & ES2 \\
\hline D. B and C combined & E03 & EM3 & ES3 \\
\hline E. A and D combined & E04 & EM4 & ES4 \\
\hline
\end{tabular}


Table 9 Impact of Trade Liberalization on Social Welfare Across Regions-as percentage of base year GDP

\begin{tabular}{|c|c|c|c|c|c|c|c|c|c|c|c|c|c|}
\hline $\begin{array}{l}\text { Import-TFP } \\
\text { link }\end{array}$ & $\begin{array}{l}\text { Experi- } \\
\text { ment }\end{array}$ & Protection Change & $\begin{array}{l}\text { United } \\
\text { States }\end{array}$ & EU15 & Japan & $\begin{array}{l}\text { Other } \\
\text { OECD }\end{array}$ & $\begin{array}{l}\text { Asia } \\
\text { NICs }\end{array}$ & China & ASEAN & $\begin{array}{l}\text { South } \\
\text { Asia }\end{array}$ & $\begin{array}{l}\text { Latin } \\
\text { America }\end{array}$ & $\begin{array}{l}\text { Rest of } \\
\text { The } \\
\text { World }\end{array}$ & $\begin{array}{l}\text { World } \\
\text { Total }\end{array}$ \\
\hline \multirow[t]{5}{*}{ not assumed } & E00 & $50 \%$ cut in shipping & 0.24 & 0.19 & 0.20 & 0.68 & 1.15 & 1.07 & 1.29 & 0.72 & 0.38 & 0.56 & 0.36 \\
\hline & E01 & Non-service sectors & 0.03 & 0.23 & 0.78 & -0.30 & 2.06 & 0.26 & -0.28 & 0.03 & -0.34 & -0.50 & 0.20 \\
\hline & E02 & $50 \%$ cut in services & 0.84 & 1.22 & 0.43 & 1.39 & 1.85 & 0.34 & 1.29 & 1.13 & 0.98 & 2.12 & 1.05 \\
\hline & E03 & $\mathrm{E} 01+\mathrm{E} 02$ & 0.87 & 1.46 & 1.22 & 1.09 & 3.76 & 0.62 & 1.01 & 1.21 & 0.66 & 1.64 & 1.26 \\
\hline & E04 & $\mathrm{E} 00+\mathrm{E} 03$ & 1.11 & 1.66 & 1.44 & 1.75 & 4.96 & 1.70 & 2.32 & 2.02 & 1.04 & 2.22 & 1.62 \\
\hline \multirow{5}{*}{$\begin{array}{l}\text { Via } \\
\text { intermediates } \\
\text { And durable }\end{array}$} & EM0 & $50 \%$ cut in shipping & 0.36 & 0.37 & 0.40 & 0.82 & 1.57 & 1.71 & 1.56 & 0.94 & 0.85 & 0.80 & 0.56 \\
\hline & EM1 & Non-service sectors & -0.06 & 0.15 & 0.89 & -0.44 & 2.86 & 5.40 & 0.58 & 3.18 & 1.16 & 0.51 & 0.54 \\
\hline & EM2 & $50 \%$ cut in services & 0.98 & 1.20 & 0.42 & 1.44 & 2.02 & 0.42 & 1.36 & 1.16 & 0.98 & 2.19 & 1.10 \\
\hline & EM3 & $\mathrm{E} 01+\mathrm{E} 02$ & 0.92 & 1.35 & 1.27 & 0.99 & 4.71 & 5.85 & 1.94 & 4.50 & 2.19 & 2.76 & 1.64 \\
\hline & EM4 & $\mathrm{E} 00+\mathrm{E} 03$ & 1.29 & 1.72 & 1.69 & 1.79 & 6.38 & 7.85 & 3.56 & 5.71 & 3.12 & 3.65 & 2.23 \\
\hline \multirow{5}{*}{$\begin{array}{l}\text { Via trade \& } \\
\text { Transport and } \\
\text { Private } \\
\text { services }\end{array}$} & ESO & $50 \%$ cut in shipping & 0.24 & 0.21 & 0.21 & 0.72 & 1.26 & 1.11 & 1.32 & 0.75 & 0.40 & 0.58 & 0.37 \\
\hline & ES1 & Non-service sectors & 0.02 & 0.28 & 1.05 & -0.33 & 2.45 & 0.33 & -0.25 & -0.06 & -0.42 & -0.55 & 0.27 \\
\hline & ES2 & $50 \%$ cut in services & 2.22 & 4.10 & 2.45 & 2.81 & 3.97 & 1.55 & 1.83 & 2.26 & 2.48 & 3.57 & 2.99 \\
\hline & ES3 & $\mathrm{E} 01+\mathrm{E} 02$ & 2.22 & 4.42 & 3.63 & 2.45 & 6.45 & 1.95 & 1.61 & 2.25 & 2.02 & 3.01 & 3.30 \\
\hline & ES4 & $\mathrm{E} 00+\mathrm{E} 03$ & 2.48 & 4.68 & 3.88 & 3.17 & 7.87 & 3.14 & 2.97 & 3.14 & 2.45 & 3.63 & 3.71 \\
\hline
\end{tabular}

Table 10 Impact of Trade Liberalization on Total Exports Across Regions-percent change from base

\begin{tabular}{|c|c|c|c|c|c|c|c|c|c|c|c|c|c|}
\hline $\begin{array}{l}\text { Import-TFP } \\
\text { link }\end{array}$ & $\begin{array}{l}\text { Experi } \\
\text {-ment }\end{array}$ & Pro & $\begin{array}{l}\text { United } \\
\text { States }\end{array}$ & EU15 & Japan & $\begin{array}{l}\text { Other } \\
\text { OECD }\end{array}$ & $\begin{array}{l}\text { Asia } \\
\text { NICs }\end{array}$ & China & ASEAN & $\begin{array}{l}\text { South } \\
\text { Asia }\end{array}$ & $\begin{array}{l}\text { Latin } \\
\text { America }\end{array}$ & $\begin{array}{l}\text { Rest of } \\
\text { the World }\end{array}$ & $\begin{array}{l}\text { World } \\
\text { Total }\end{array}$ \\
\hline not & $\begin{array}{l}\text { E00 } \\
\text { E01 } \\
\text { E02 } \\
\text { E03 } \\
\text { E04 }\end{array}$ & $\begin{array}{l}50 \% \text { cut in shipping } \\
\text { Non-service sectors } \\
50 \% \text { cut in services } \\
\text { E01 + E02 } \\
\text { E00 + E03 }\end{array}$ & $\begin{array}{l}5.23 \\
7.18 \\
11.97 \\
19.22 \\
25.12\end{array}$ & $\begin{array}{l}4.31 \\
11.17 \\
13.89 \\
25.26 \\
30.36\end{array}$ & $\begin{array}{l}4.02 \\
12.8 \\
9.64 \\
22.72 \\
27.49\end{array}$ & $\begin{array}{l}4.87 \\
3.16 \\
8.27 \\
11.39 \\
16.87\end{array}$ & $\begin{array}{l}5.07 \\
15.62 \\
6.91 \\
22.71 \\
28.84\end{array}$ & $\begin{array}{l}5.10 \\
46.62 \\
2.43 \\
49.10 \\
56.40\end{array}$ & $\begin{array}{l}4.81 \\
15.08 \\
4.68 \\
19.70 \\
25.30\end{array}$ & $\begin{array}{l}4.52 \\
72.35 \\
8.57 \\
81.34 \\
88.23\end{array}$ & $\begin{array}{l}6.62 \\
20.55 \\
11.15 \\
31.91 \\
39.87\end{array}$ & $\begin{array}{l}5.49 \\
18.47 \\
11.57 \\
30.38 \\
37.09\end{array}$ & $\begin{array}{l}4.86 \\
14.15 \\
10.16 \\
24.47 \\
30.26\end{array}$ \\
\hline $\begin{array}{l}\text { Via } \\
\text { intermediates } \\
\text { and durable }\end{array}$ & $\begin{array}{l}\text { EM0 } \\
\text { EM1 } \\
\text { EM2 } \\
\text { EM3 } \\
\text { EM4 }\end{array}$ & $\begin{array}{l}50 \% \text { cut in shipping } \\
\text { Non-service sectors } \\
50 \% \text { cut in services } \\
\text { E01 + E02 } \\
\text { E00 + E03 }\end{array}$ & $\begin{array}{l}5.19 \\
6.82 \\
12.03 \\
18.95 \\
24.82\end{array}$ & $\begin{array}{l}4.39 \\
10.95 \\
13.73 \\
24.81 \\
30.03\end{array}$ & $\begin{array}{l}4.09 \\
12.56 \\
9.45 \\
22.17 \\
27.07\end{array}$ & $\begin{array}{l}4.83 \\
2.80 \\
8.20 \\
10.90 \\
16.31\end{array}$ & $\begin{array}{l}5.30 \\
16.62 \\
6.98 \\
23.83 \\
30.39\end{array}$ & $\begin{array}{l}5.37 \\
49.88 \\
2.39 \\
52.36 \\
60.51\end{array}$ & $\begin{array}{l}4.87 \\
16.09 \\
4.60 \\
20.64 \\
26.41\end{array}$ & $\begin{array}{l}4.77 \\
76.05 \\
8.52 \\
85.40 \\
93.15\end{array}$ & $\begin{array}{l}6.53 \\
20.16 \\
11.13 \\
31.53 \\
39.54\end{array}$ & $\begin{array}{l}5.67 \\
19.24 \\
11.50 \\
31.12 \\
38.15\end{array}$ & $\begin{array}{l}4.94 \\
14.41 \\
10.10 \\
24.65 \\
30.62\end{array}$ \\
\hline $\begin{array}{l}\text { Via trade \& } \\
\text { Transport and } \\
\text { Private } \\
\text { services }\end{array}$ & $\begin{array}{l}\text { ES0 } \\
\text { ES1 } \\
\text { ES2 } \\
\text { ES3 } \\
\text { ES4 }\end{array}$ & $\begin{array}{l}50 \% \text { cut in shipping } \\
\text { Non-service sectors } \\
50 \% \text { cut in services } \\
\text { E01 + E02 } \\
\text { E00 + E03 }\end{array}$ & $\begin{array}{l}5.24 \\
7.18 \\
13.83 \\
21.21 \\
27.24\end{array}$ & $\begin{array}{l}4.33 \\
11.21 \\
16.72 \\
28.49 \\
33.78\end{array}$ & $\begin{array}{l}4.03 \\
13.00 \\
11.12 \\
24.67 \\
29.54\end{array}$ & $\begin{array}{l}4.90 \\
3.14 \\
9.63 \\
12.74 \\
18.34\end{array}$ & $\begin{array}{l}5.16 \\
16.01 \\
9.07 \\
25.66 \\
32.09\end{array}$ & $\begin{array}{l}5.14 \\
46.74 \\
3.73 \\
51.30 \\
58.84\end{array}$ & $\begin{array}{l}4.83 \\
15.13 \\
5.32 \\
20.44 \\
26.15\end{array}$ & $\begin{array}{l}4.56 \\
72.23 \\
10.98 \\
84.55 \\
91.69\end{array}$ & $\begin{array}{l}6.64 \\
20.53 \\
13.13 \\
34.15 \\
42.28\end{array}$ & $\begin{array}{l}5.50 \\
18.46 \\
13.65 \\
32.72 \\
39.59\end{array}$ & $\begin{array}{l}4.89 \\
14.23 \\
12.10 \\
26.75 \\
32.71\end{array}$ \\
\hline
\end{tabular}


Table 11 Impact of Trade Liberalization on Each Region's Total Factor Productivity—percent change from base

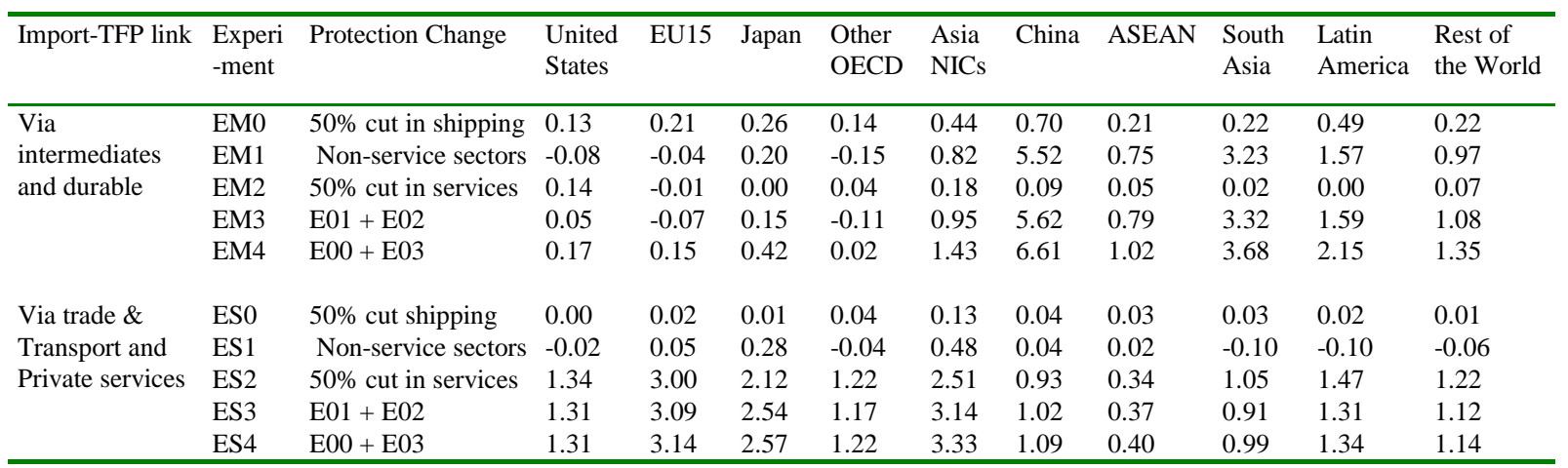

Table 12 Impact of Reduction in International Shipping Margin on Each Regions Output and Exports-percent change from base

\begin{tabular}{|c|c|c|c|c|c|c|c|c|c|c|}
\hline Sectors & $\begin{array}{l}\text { United } \\
\text { States }\end{array}$ & EU15 & Japan & $\begin{array}{l}\text { Other } \\
\text { OECD }\end{array}$ & $\begin{array}{l}\text { Asia } \\
\text { NICs }\end{array}$ & China & ASEAN & $\begin{array}{l}\text { South } \\
\text { Asia }\end{array}$ & $\begin{array}{l}\text { Latin } \\
\text { America }\end{array}$ & $\begin{array}{l}\text { Rest of } \\
\text { the World }\end{array}$ \\
\hline & \multicolumn{10}{|c|}{ Output } \\
\hline Agriculture & 1.18 & -0.30 & -1.72 & 0.22 & -0.23 & 1.14 & 0.60 & 0.46 & 0.92 & 0.38 \\
\hline Processed food & 0.00 & 0.05 & -0.55 & 0.62 & 0.46 & 0.70 & 2.23 & 1.25 & 0.48 & -0.03 \\
\hline Resource based & 0.16 & -0.65 & -1.68 & 2.27 & -1.43 & 0.94 & 0.76 & -1.52 & 0.85 & 0.99 \\
\hline Consumer goods & -0.48 & -0.17 & -0.66 & 0.87 & 3.46 & 2.75 & 3.77 & 1.67 & 0.52 & 1.49 \\
\hline Intermediate and durable & 0.51 & 0.36 & 0.50 & 1.03 & 1.83 & -0.77 & -0.14 & -1.80 & -0.96 & -0.02 \\
\hline Utility & 0.25 & 0.25 & 0.12 & 0.60 & 1.49 & 0.74 & 1.22 & 0.36 & 0.29 & 0.49 \\
\hline Construction & 0.03 & 0.06 & 0.02 & 0.08 & 0.14 & 0.01 & 0.07 & 0.10 & 0.02 & 0.06 \\
\hline Trade and transport & -0.33 & -0.29 & -0.12 & -1.08 & 1.57 & -0.18 & -1.53 & 0.43 & -0.29 & -1.15 \\
\hline Private services & 0.17 & 0.26 & 0.31 & 0.41 & 1.00 & 0.45 & 1.03 & 0.61 & 0.27 & 0.48 \\
\hline Public services & 0.10 & 0.11 & 0.28 & 0.25 & 0.66 & 0.46 & 0.52 & 0.46 & 0.15 & 0.30 \\
\hline \multirow[t]{2}{*}{ Housing } & 0.18 & 0.22 & -0.75 & 0.55 & 1.43 & 0.98 & 1.57 & 0.57 & 0.47 & 0.73 \\
\hline & \multicolumn{10}{|c|}{ Exports } \\
\hline Agriculture & 9.87 & 13.18 & 13.80 & 4.13 & 13.13 & 0.67 & 0.78 & 1.77 & 7.61 & 8.73 \\
\hline Processed food & 6.55 & 6.85 & 9.39 & 7.10 & 8.18 & -0.57 & 9.73 & 11.80 & 5.38 & 9.33 \\
\hline Resource based & 22.40 & 10.40 & 20.24 & 7.93 & 28.98 & 18.47 & 5.92 & -1.94 & 10.12 & 3.59 \\
\hline Consumer goods & 8.70 & 6.87 & 8.03 & 7.68 & 8.52 & 6.29 & 7.05 & 5.26 & 6.05 & 8.98 \\
\hline Intermediate and durable & 5.39 & 4.27 & 3.90 & 4.32 & 5.92 & 3.47 & 4.13 & 6.25 & 7.76 & 7.67 \\
\hline Utility & 0.00 & 2.20 & 0.00 & -1.62 & 0.96 & 1.09 & 0.00 & 0.00 & 0.00 & 0.73 \\
\hline Construction & 0.00 & 0.24 & 0.00 & -0.79 & 0.86 & 0.00 & 0.12 & 0.00 & -0.66 & -0.15 \\
\hline Trade and transport & 1.51 & 1.12 & 1.74 & -0.77 & -1.09 & -1.62 & -1.10 & -1.49 & -0.07 & 0.55 \\
\hline Private services & 1.19 & 0.65 & 1.63 & -1.19 & -1.36 & -1.76 & -0.93 & -1.68 & -0.49 & 0.26 \\
\hline Public services & 1.28 & 0.84 & 1.87 & -0.72 & -1.50 & -1.50 & -1.29 & -1.73 & -0.27 & 0.58 \\
\hline Housing & 0.00 & 0.00 & 0.00 & 0.00 & 0.00 & 0.00 & 0.00 & 0.00 & 0.00 & 0.00 \\
\hline
\end{tabular}


Table 13 Impact of Service Sector Trade Liberalization on Each Region's Output and Exports by Sector-percent change from base

\begin{tabular}{|c|c|c|c|c|c|c|c|c|c|c|}
\hline Sectors & $\begin{array}{l}\text { United } \\
\text { States }\end{array}$ & EU15 & Japan & $\begin{array}{l}\text { Other } \\
\text { OECD }\end{array}$ & $\begin{array}{l}\text { Asia } \\
\text { NICs }\end{array}$ & China & ASEAN & $\begin{array}{l}\text { South } \\
\text { Asia }\end{array}$ & $\begin{array}{l}\text { Latin } \\
\text { America }\end{array}$ & $\begin{array}{l}\text { Rest of } \\
\text { The World }\end{array}$ \\
\hline Experiment E02 & \multicolumn{10}{|c|}{ Output: without trade-TFP linkage } \\
\hline Agriculture & 0.02 & 1.19 & 0.62 & 1.36 & 0.04 & 0.25 & 0.02 & 0.70 & 0.71 & 1.13 \\
\hline Processed food & -0.11 & 0.67 & 0.29 & 1.00 & 0.03 & 0.26 & -0.12 & 0.97 & 0.53 & 1.17 \\
\hline Resource based & -0.78 & 2.27 & 1.33 & 1.86 & -2.01 & 0.04 & -1.09 & 0.90 & 1.16 & 1.42 \\
\hline Consumer goods & -0.61 & 1.92 & 0.87 & 2.85 & -1.82 & -0.63 & -1.51 & 1.99 & 1.52 & 2.27 \\
\hline Intermediates \& durable & -1.07 & 2.04 & 1.32 & 2.50 & -3.14 & -0.38 & -2.47 & 1.34 & 1.34 & 2.08 \\
\hline Utility & 0.37 & 1.02 & 0.53 & 1.12 & 0.06 & 0.34 & 1.41 & 1.39 & 0.87 & 1.94 \\
\hline Construction & 0.14 & 0.31 & 0.02 & -0.20 & -0.26 & -0.07 & -1.37 & 0.22 & -1.82 & 0.35 \\
\hline Trade and transport & 1.13 & -0.69 & -0.66 & -0.08 & 8.30 & 0.79 & 4.64 & -2.52 & -1.30 & -0.06 \\
\hline Private services & 0.59 & 0.27 & -0.07 & -1.79 & -1.37 & 2.34 & 4.07 & 2.56 & -0.30 & -1.03 \\
\hline Public services & 0.26 & -1.17 & -0.01 & 0.46 & -1.81 & 0.65 & -3.37 & 0.89 & 1.31 & 0.42 \\
\hline Housing & 0.42 & 0.61 & 0.94 & 0.50 & 1.71 & 1.10 & 1.59 & 0.71 & 0.91 & 1.93 \\
\hline Experiment E02 & \multicolumn{10}{|c|}{ Exports: without trade-TFP linkage } \\
\hline Agriculture & -0.34 & 4.60 & 4.20 & 1.79 & -2.59 & -1.20 & -1.74 & -1.53 & 0.79 & -1.04 \\
\hline Processed food & -4.32 & 3.95 & 4.56 & 2.47 & -4.49 & -2.41 & -3.19 & 0.99 & 1.06 & 0.08 \\
\hline Resource based & -2.17 & 4.54 & 3.97 & 1.25 & -4.22 & -1.43 & -2.24 & -0.15 & 2.39 & -0.00 \\
\hline Consumer goods & -5.27 & 5.77 & 5.82 & 4.71 & -4.28 & -1.86 & -3.33 & 3.18 & 4.19 & 2.08 \\
\hline Intermediate \& durable & -4.67 & 5.27 & 4.27 & 3.03 & -5.18 & -1.61 & -3.66 & 2.91 & 3.06 & 3.05 \\
\hline Utility & 0.00 & 2.78 & 0.00 & 1.97 & -3.87 & 4.78 & 0.00 & 0.00 & 0.00 & -0.53 \\
\hline Construction & 0.00 & 38.42 & 0.00 & 75.25 & 48.79 & 0.00 & 53.67 & 0.00 & 49.16 & 50.45 \\
\hline Trade and transport & 54.50 & 48.81 & 62.99 & 39.94 & 45.64 & 51.55 & 50.36 & 53.23 & 54.82 & 59.17 \\
\hline Private services & 60.76 & 49.80 & 52.50 & 43.98 & 47.40 & 50.77 & 50.54 & 51.07 & 53.13 & 58.05 \\
\hline Public services & 60.82 & 49.06 & 46.95 & 63.02 & 48.26 & 53.47 & 53.61 & 54.07 & 58.02 & 58.56 \\
\hline Housing & 0.00 & 0.00 & 0.00 & 0.00 & 0.00 & 0.00 & 0.00 & 0.00 & 0.00 & 0.00 \\
\hline Experiment EM2 & \multicolumn{10}{|c|}{ TFP growth: via durable as intermediate inputs } \\
\hline Agriculture & 0.01 & 0.00 & 0.00 & 0.01 & 0.00 & 0.03 & 0.01 & 0.01 & 0.00 & 0.03 \\
\hline Processed food & 0.01 & 0.00 & 0.00 & 0.01 & 0.01 & 0.01 & 0.01 & 0.00 & 0.00 & 0.02 \\
\hline Resource based & 0.02 & 0.00 & 0.00 & 0.01 & 0.01 & 0.04 & 0.01 & 0.00 & 0.00 & 0.04 \\
\hline Consumer goods & 0.05 & 0.00 & 0.00 & 0.02 & 0.05 & 0.06 & 0.04 & 0.03 & 0.00 & 0.04 \\
\hline Intermediate \& durable & 0.68 & -0.05 & 0.00 & 0.23 & 0.77 & 0.40 & 0.25 & 0.08 & 0.02 & 0.35 \\
\hline Utility & 0.01 & 0.00 & 0.00 & 0.00 & 0.00 & 0.01 & 0.01 & 0.01 & 0.00 & 0.01 \\
\hline Construction & 0.07 & 0.00 & 0.00 & 0.02 & 0.06 & 0.05 & 0.06 & 0.02 & 0.00 & 0.05 \\
\hline Trade and transport & 0.03 & 0.00 & 0.00 & 0.02 & 0.07 & 0.03 & 0.02 & 0.01 & 0.00 & 0.03 \\
\hline Private services & 0.03 & 0.00 & 0.00 & 0.02 & 0.07 & 0.03 & 0.02 & 0.01 & 0.00 & 0.03 \\
\hline Public services & 0.02 & 0.00 & 0.00 & 0.01 & 0.03 & 0.01 & 0.00 & 0.00 & 0.00 & 0.05 \\
\hline Housing & 0.00 & 0.00 & 0.00 & 0.00 & 0.00 & 0.00 & 0.01 & 0.00 & 0.00 & 0.00 \\
\hline Experiment ES2 & \multicolumn{10}{|c|}{ TFP growth: via services as intermediate inputs } \\
\hline Agriculture & 0.29 & 0.16 & 0.09 & 0.13 & 0.07 & 0.12 & 0.01 & 1.03 & 0.05 & 0.21 \\
\hline Processed food & 0.14 & 0.93 & 1.52 & 0.41 & 0.28 & 0.43 & 0.13 & 1.25 & 1.29 & 0.71 \\
\hline Resource based & 0.05 & 0.46 & 0.19 & 0.29 & 0.16 & 0.40 & 0.07 & 0.27 & 0.65 & 0.55 \\
\hline Consumer goods & 0.39 & 1.20 & 0.81 & 0.59 & 0.75 & 0.63 & 0.14 & 2.82 & 0.79 & 0.73 \\
\hline Intermediate \& durable & 2.01 & 4.03 & 2.77 & 1.50 & 2.09 & 0.74 & 0.32 & 2.15 & 2.82 & 2.45 \\
\hline Utility & 0.13 & 0.13 & 0.13 & 0.07 & 0.03 & 0.13 & 0.02 & 0.50 & 0.08 & 0.15 \\
\hline Construction & 1.05 & 0.51 & 0.54 & 0.44 & 0.37 & 0.10 & 0.27 & 1.50 & 0.40 & 0.67 \\
\hline Trade and transport & 0.68 & 4.57 & 4.90 & 2.32 & 6.94 & 1.50 & 0.89 & 1.11 & 4.96 & 2.51 \\
\hline Private services & 3.22 & 5.12 & 1.48 & 1.88 & 2.01 & 2.79 & 0.41 & 0.08 & 0.57 & 0.92 \\
\hline Public services & 0.44 & 1.07 & 0.03 & 0.65 & 0.27 & 3.55 & 0.09 & 0.46 & 0.42 & 1.03 \\
\hline Housing & 0.15 & 0.01 & 0.00 & 0.02 & 0.01 & 0.04 & 0.21 & 0.10 & 0.10 & 0.02 \\
\hline
\end{tabular}


Table 14 Impact of Total Trade Liberalization on Each Region's output by Sector-percent change from base

\begin{tabular}{|c|c|c|c|c|c|c|c|c|c|c|}
\hline Sectors & $\begin{array}{l}\text { United } \\
\text { States }\end{array}$ & EU15 & Japan & $\begin{array}{l}\text { Other } \\
\text { OECD }\end{array}$ & $\begin{array}{l}\text { Asia } \\
\text { NICs }\end{array}$ & China & ASEAN & $\begin{array}{l}\text { South } \\
\text { Asia }\end{array}$ & $\begin{array}{l}\text { Latin } \\
\text { America }\end{array}$ & $\begin{array}{l}\text { Rest of } \\
\text { the World }\end{array}$ \\
\hline Experiment E04 & \multicolumn{10}{|c|}{ Without trade-TFP linkage } \\
\hline Agriculture & 6.53 & 0.12 & -16.49 & 4.08 & -3.62 & 4.48 & 0.19 & 3.76 & 4.25 & 2.93 \\
\hline Processed food & -0.18 & 0.10 & -4.66 & 7.84 & 3.98 & 2.30 & 2.91 & 4.20 & 4.12 & 0.51 \\
\hline Resource based & -1.22 & 1.07 & -2.47 & 4.19 & -6.23 & 3.51 & -0.05 & 0.63 & 2.77 & 4.12 \\
\hline Consumer goods & -7.32 & -2.53 & -2.13 & -6.21 & 24.92 & 32.50 & 15.60 & 31.46 & 3.72 & 7.13 \\
\hline Intermediate \& durable & 0.11 & 4.29 & 3.73 & 3.79 & 1.92 & -3.69 & -1.02 & -24.35 & -3.78 & -1.14 \\
\hline Utility & 0.66 & 1.58 & 1.26 & 1.67 & 6.04 & 5.29 & 5.73 & 6.81 & 1.16 & 2.92 \\
\hline Construction & 0.24 & 0.38 & 0.11 & -0.05 & -0.23 & 0.11 & -0.98 & 1.21 & -1.59 & 0.86 \\
\hline Trade and transport & 1.25 & -0.69 & -0.16 & -0.14 & 5.23 & 5.39 & 4.42 & 2.48 & -0.26 & 1.04 \\
\hline Private services & 1.27 & 0.80 & 1.17 & -0.78 & 0.11 & 6.74 & 6.31 & 6.52 & 0.39 & 0.66 \\
\hline Public services & 0.43 & -1.15 & 1.14 & 1.00 & -1.78 & 1.70 & -3.24 & 5.09 & 1.94 & 1.32 \\
\hline Housing & 0.54 & 1.02 & -3.88 & 0.66 & 5.02 & 6.14 & 3.49 & 2.47 & 1.14 & 1.94 \\
\hline Experiment EM4 & \multicolumn{10}{|c|}{ With trade-TFP linkage: $v$} \\
\hline Agriculture & 7.80 & 1.25 & -16.01 & 5.55 & -3.27 & 10.05 & 0.67 & 6.88 & 4.50 & 3.88 \\
\hline Processed food & 0.23 & 0.75 & -4.31 & 8.63 & 4.46 & 7.91 & 3.27 & 7.13 & 4.63 & 1.31 \\
\hline Resource based & -0.92 & 1.71 & -1.86 & 4.80 & -5.70 & 8.89 & 0.13 & -0.35 & 3.13 & 5.11 \\
\hline Consumer goods & -6.22 & -1.33 & -1.15 & -4.64 & 26.60 & 27.26 & 16.37 & 36.52 & 4.96 & 7.94 \\
\hline Intermediate $\&$ durable & -0.57 & 3.43 & 3.54 & 1.32 & 4.36 & 9.05 & 1.69 & -16.21 & 1.83 & 1.41 \\
\hline Utility & 0.79 & 1.66 & 1.30 & 1.62 & 7.70 & 13.12 & 7.20 & 10.81 & 3.54 & 4.38 \\
\hline Construction & 0.29 & 0.44 & 0.15 & -0.02 & -0.09 & 0.28 & -0.92 & 1.89 & -1.49 & 1.03 \\
\hline Trade and transport & 1.65 & -0.34 & 0.36 & 0.30 & 6.37 & 10.27 & 5.36 & 6.92 & 1.83 & 2.28 \\
\hline Private services & 1.56 & 1.00 & 1.66 & -0.58 & 1.09 & 10.72 & 7.22 & 8.69 & 2.53 & 1.94 \\
\hline Public services & 0.56 & -0.97 & 1.49 & 1.29 & -1.07 & 4.37 & -2.85 & 6.61 & 2.17 & 2.10 \\
\hline Housing & 0.68 & 1.11 & -3.58 & 0.71 & 6.65 & 12.89 & 5.16 & 5.71 & 3.77 & 3.61 \\
\hline Experiment ES4 & \multicolumn{10}{|c|}{ With trade-TFP linkage: via services as intermediate inputs } \\
\hline Agriculture & 8.41 & 1.41 & -15.89 & 5.39 & -2.79 & 6.16 & 0.68 & 4.86 & 4.98 & 3.99 \\
\hline Processed food & 0.65 & 1.33 & -3.77 & 8.91 & 5.29 & 3.81 & 3.59 & 5.41 & 5.00 & 1.55 \\
\hline Resource based & 0.16 & 3.43 & -1.50 & 5.69 & -5.16 & 4.93 & 0.91 & 0.77 & 4.14 & 5.53 \\
\hline Consumer goods & -6.01 & 0.49 & -0.84 & -4.35 & 28.42 & 35.96 & 18.11 & 35.36 & 5.35 & 9.34 \\
\hline Intermediate $\&$ durable & 1.63 & 7.86 & 5.00 & 4.40 & 3.37 & -3.26 & -1.99 & -25.14 & -2.66 & -0.51 \\
\hline Utility & 2.08 & 4.81 & 2.70 & 2.93 & 9.05 & 6.83 & 6.50 & 8.01 & 2.64 & 4.27 \\
\hline Construction & 0.59 & 1.26 & 0.37 & 0.18 & 0.15 & 0.15 & -0.86 & 1.43 & -1.45 & 1.08 \\
\hline Trade and transport & 3.42 & 3.92 & 4.53 & 2.06 & 13.67 & 6.52 & 5.15 & 3.61 & 2.48 & 2.83 \\
\hline Private services & 2.85 & 5.45 & 4.65 & 0.64 & 3.76 & 8.55 & 6.75 & 6.89 & 1.85 & 1.83 \\
\hline Public services & 0.95 & 0.05 & 3.10 & 1.82 & -0.25 & 2.82 & -2.78 & 6.02 & 2.49 & 2.29 \\
\hline Housing & 1.71 & 3.96 & -2.59 & 1.68 & 8.18 & 7.78 & 4.37 & 3.40 & 2.82 & 3.51 \\
\hline
\end{tabular}


Table 15 Impact of Total Trade Liberalization on Each Region's Exports by Sector-percent change from base

\begin{tabular}{|c|c|c|c|c|c|c|c|c|c|c|}
\hline Sectors & $\begin{array}{l}\text { United } \\
\text { States }\end{array}$ & EU15 & Japan & $\begin{array}{l}\text { Other } \\
\text { OECD }\end{array}$ & $\begin{array}{l}\text { Asia } \\
\text { NICs }\end{array}$ & China & ASEAN & $\begin{array}{l}\text { South } \\
\text { Asia }\end{array}$ & $\begin{array}{l}\text { Latin } \\
\text { America }\end{array}$ & $\begin{array}{l}\text { Rest of } \\
\text { the World }\end{array}$ \\
\hline Experiment E04 & \multicolumn{10}{|c|}{ Without trade-TFP linkage } \\
\hline Agriculture & 44.79 & 45.53 & 43.99 & 18.53 & 12.46 & -24.44 & 3.18 & 16.38 & 18.07 & 35.69 \\
\hline Processed food & 16.69 & 37.96 & 49.95 & 65.94 & 66.40 & 4.05 & 21.03 & 52.78 & 41.35 & 49.80 \\
\hline Resource based & 21.50 & 17.01 & 28.18 & 10.42 & 31.20 & 32.79 & 2.47 & 29.88 & 26.10 & 11.42 \\
\hline Consumer goods & 3.39 & 21.77 & 80.77 & -1.77 & 61.13 & 92.00 & 35.13 & 129.05 & 50.13 & 62.50 \\
\hline Intermediate \& durable & 7.62 & 25.33 & 19.71 & 10.13 & 14.67 & 51.58 & 23.08 & 169.01 & 43.09 & 43.29 \\
\hline Utility & 0.00 & 0.78 & 0.00 & 2.23 & -9.58 & 24.98 & 0.00 & 0.00 & 0.00 & 10.82 \\
\hline Construction & 0.00 & 32.89 & 0.00 & 76.52 & 33.15 & 0.00 & 60.09 & 0.00 & 62.17 & 62.35 \\
\hline Trade and transport & 61.24 & 48.84 & 56.73 & 47.14 & 27.44 & 50.79 & 49.50 & 88.14 & 74.01 & 75.87 \\
\hline Private services & 67.69 & 49.86 & 46.73 & 50.90 & 28.30 & 49.55 & 50.17 & 79.19 & 70.03 & 72.45 \\
\hline Public services & 65.20 & 46.32 & 40.22 & 68.45 & 23.22 & 50.66 & 46.11 & 78.22 & 71.34 & 70.55 \\
\hline Housing & 0.00 & 0.00 & 0.00 & 0.00 & 0.00 & 0.00 & 0.00 & 0.00 & 0.00 & 0.00 \\
\hline Experiment EM4 & \multicolumn{10}{|c|}{ With trade-TFP linkage: via durable as intermediate input } \\
\hline Agriculture & 49.03 & 52.41 & 55.11 & 22.94 & 13.88 & -40.87 & 3.11 & 24.60 & 12.86 & 36.92 \\
\hline Processed food & 19.59 & 42.39 & 57.00 & 69.43 & 64.56 & -14.67 & 20.05 & 49.93 & 34.70 & 47.63 \\
\hline Resource based & 24.88 & 21.65 & 33.90 & 13.15 & 31.02 & 19.11 & 0.77 & 14.33 & 18.76 & 11.78 \\
\hline Consumer goods & 7.63 & 27.00 & 91.69 & 1.51 & 62.65 & 75.32 & 35.38 & 135.48 & 40.80 & 60.65 \\
\hline Intermediate \& durable & 4.66 & 21.82 & 19.15 & 5.70 & 17.95 & 81.13 & 26.89 & 211.63 & 63.92 & 48.05 \\
\hline Utility & 0.00 & 0.93 & 0.00 & 2.96 & 1.49 & 19.94 & 0.00 & 0.00 & 0.00 & 6.55 \\
\hline Construction & 0.00 & 34.85 & 0.00 & 79.19 & 32.09 & 0.00 & 60.51 & 0.00 & 53.98 & 62.55 \\
\hline Trade and transport & 64.91 & 53.38 & 59.58 & 51.28 & 26.65 & 35.19 & 47.28 & 72.75 & 63.69 & 74.05 \\
\hline Private services & 70.83 & 53.23 & 49.90 & 54.30 & 24.50 & 29.40 & 47.82 & 57.50 & 53.34 & 68.36 \\
\hline Public services & 68.76 & 50.20 & 43.29 & 73.42 & 20.93 & 34.64 & 43.98 & 58.27 & 57.11 & 71.00 \\
\hline Housing & 0.00 & 0.00 & 0.00 & 0.00 & 0.00 & 0.00 & 0.00 & 0.00 & 0.00 & 0.00 \\
\hline Experiment ES4 & \multicolumn{10}{|c|}{ With trade-TFP linkage: via services as intermediate inputs } \\
\hline Agriculture & 49.66 & 45.56 & 45.95 & 20.60 & 10.79 & -26.46 & 4.12 & 20.38 & 18.03 & 37.52 \\
\hline Processed food & 18.12 & 38.56 & 54.66 & 68.43 & 64.81 & 3.07 & 22.45 & 54.71 & 42.78 & 51.47 \\
\hline Resource based & 23.55 & 16.67 & 29.56 & 12.58 & 31.11 & 38.44 & 4.70 & 29.59 & 29.04 & 13.79 \\
\hline Consumer goods & 5.43 & 23.04 & 83.24 & 0.69 & 64.74 & 97.44 & 39.03 & 138.89 & 51.83 & 67.46 \\
\hline Intermediate $\&$ durable & 9.36 & 30.60 & 21.83 & 10.47 & 15.47 & 51.44 & 21.80 & 162.85 & 44.66 & 44.26 \\
\hline Utility & 0.00 & 0.48 & 0.00 & 4.32 & -11.56 & 34.12 & 0.00 & 0.00 & 0.00 & 16.34 \\
\hline Construction & 0.00 & 31.44 & 0.00 & 79.26 & 33.53 & 0.00 & 63.57 & 0.00 & 62.23 & 64.20 \\
\hline Trade and transport & 58.35 & 53.86 & 67.19 & 49.73 & 45.19 & 51.74 & 49.47 & 81.30 & 83.17 & 78.25 \\
\hline Private services & 77.17 & 56.45 & 43.10 & 53.16 & 28.04 & 56.15 & 49.90 & 69.75 & 63.55 & 69.55 \\
\hline Public services & 69.42 & 45.43 & 36.29 & 73.62 & 20.78 & 67.84 & 49.94 & 77.44 & 72.00 & 75.76 \\
\hline Housing & 0.00 & 0.00 & 0.00 & 0.00 & 0.00 & 0.00 & 0.00 & 0.00 & 0.00 & 0.00 \\
\hline
\end{tabular}

